\title{
The composition and new records of micro- and mesophytoplankton near the Vitória-Trindade Seamount Chain
}

\author{
Karoline Magalhães Ferreira Lubiana ${ }^{1,2,3}$ \& Camilo Dias Júnior ${ }^{I}$ \\ ${ }^{1}$ Universidade Federal do Espirito Santo, Departamento de Oceanografia e Ecologia, Vitoria, ES, Brazil \\ ${ }^{2}$ Universidade de São Paulo, Instituto de Biociências, Departamento de Botânica, São Paulo, SP, Brazil \\ ${ }^{3}$ Corresponding author: Karoline Magalhães Ferreira Lubiana, e-mail: karolinemfl@usp.br
}

LUBIANA, K.M.F., DIAS JÚNIOR, C. The composition and new records of micro- and mesophytoplankton near the Vitória-Trindade Seamount Chain. Biota Neotropica. 16(3): e20160164. http://dx.doi.org/10.1590/16760611-BN-2016-0164

\begin{abstract}
In spite of the length of the Brazilian coastline, studies of marine phytoplankton species in offshore areas have been largely neglected. Regarding phytoplankton species composition, the aim was to assess biodiversity status, species frequency, and the similarities at different sites along the Vitoria-Trindade Seamount Chain. Phytoplankton net samples were analyzed. One hundred and seventy five infrageneric taxa were identified. They represented four phyla, viz., Cyanobacteria, Bacillariophyta, Dinophyta, and Ochrophyta. Dinophyta was the most diverse, and its genus Tripos the largest contributor. This genus also represented more than half of the most common taxa in the sampled area. Thirty-five new infrageneric taxa were recorded, 12 of which are new reports for Brazil. Neritic stations assemblages were markedly different from those of seamounts and deep offshore. The high species diversity, especially among dinoflagellates can be considered typical of tropical oligotrophic waters. The new records demonstrate the gap in knowledge of phytoplankton biodiversity in Brazil.
\end{abstract}

Keywords: South Atlantic, Tripos, oceanic islands, phytoplankton, biodiversity.

LUBIANA, K.M.F., DIAS JÚNIOR, C. Composição e novos registros do micro e mesofitoplâncton nas proximidades da Cadeia Vitória-Trindade. Biota Neotropica. 16(3): e20160164. http://dx.doi.org/10.1590/16760611-BN-2016-0164

Resumo: O fitoplâncton marinho é negligenciado nas áreas fora da plataforma continental brasileira. Este estudo objetiva avaliar o status da biodiversidade, a frequência de ocorrência das espécies e a relação de proximidade entre as estações amostradas ao longo da cadeia Vitória-Trindade de acordo com a composição de espécies do fitoplâncton. Analisamos amostras de rede e identificamos 175 táxons infra genéricos de quatro filos: Cyanobacteria, Bacillariophyta, Dinophyta e Ochrophyta. Dinophyta teve o maior número de táxons e seu gênero Tripos foi o mais diversificado. Esse também representou mais da metade dos táxons muito comuns. Foram identificados 35 novos registros de táxons infra genéricos na área estudada, dentre eles 12 são novos para o Brasil. A composição de espécies nas estações neríticas foi mais distinta das estações oceânicas e sobre os montes da cadeia submersa. A alta diversidade de espécies, especialmente dinoflagelados, é típica de ambiente de águas tropicais oligotróficas. Os novos registros demonstraram a lacuna de conhecimento a respeito da biodiversidade fitoplanctônica nas regiões oceânicas no Brasil.

Palavras-chave: Atlântico Sul, Tripos, ilhas oceânicas, fitoplâncton, diversidade. 


\section{Introduction}

In spite of the long extent of the Brazilian coastline, the study of phytoplankton in offshore areas is incipient, notwithstanding the important role of this marine community as the source of more than $45 \%$ of primary production worldwide (Field 1998). Regarding group diversity, a high range in phyla is found, since many organisms are not descended from the same lineage. The greatest species-diversity is found among diatoms (13.776 species) and dinoflagellates (3.281) (Guiry \& Guiry 2015), although other groups such as haptophytes, prasinophytes and cyanobacteria, are also significant. According to Barton et al. (2010), phytoplankton composition is driven by a latitudinal gradient of species richness, whereby tropical and subtropical zones prove to be the richest.

The Vitória-Trindade Seamount Chain is located off the central coast of Brazil. Starting 175km off the coast of Espírito Santo State and extending for $950 \mathrm{~km}$ eastward, the seamounts are disposed almost linearly at $20^{\circ}$ and $21^{\circ} \mathrm{S}$ (Almeida 2006), and situated between the parallels $28^{\circ}$ and $38^{\circ} \mathrm{W}$. The chain emerged on the seafloor during the Cenozoic, simultaneously with the westward movement of the South America Plate (Almeida 2006). Trindade Island and Martin Vaz Archipelago are located at the eastern end, the farthest location from the coast (Almeida 2006, Motoki et al. 2012). The last 17 submarine banks rise higher than $2.5 \mathrm{~km}$ from the seafloor, with more than half reaching the euphotic zone (Motoki et al. 2012).

The Brazilian current, originating from the South Equatorial Current at $10^{\circ} \mathrm{S}$ (Silveira et al. 2000), passes through the region transporting an oligotrophic, warm and highly saline water mass (Brandini et al. 1997, Gaeta et al. 1999). Due to low nutrient availability, these environmental conditions favor phytoplankton species that are mixotrophic, heterotrophic or diazotrophic.

The only two studies available of phytoplankton close to the Vitória-Trindade Seamount Chain, both as a part of the REVIZEE program (Tenenbaum et al. 2006, 2007), were published in Portuguese, thereby precluding access by the international scientific community. Other organisms from this region, such as cetaceans (Wedekin et al. 2014), fishes (Pinheiro et al. 2009, 2015), barnacles (Young 1999), rhodolites (Pereira-Filho et al. 2012), etc, received more attention.

On considering the extreme importance of investigating the fundamental role of phytoplankton community in marine ecosystems, their high biodiversity in tropical waters, and the few studies currently available, the aims of this study were to assess: (i) biodiversity status, (ii) frequency of occurrence of each taxon, and (iii) station similarity, as regards taxonomic composition of micro- and mesophytoplankton communities, close to the Vitória-Trindade Seamount Chain.

\section{Material and Methods}

Samples were collected during November of the austral spring of 2003, aboard R.V. Antares of the Brazilian Navy. Collection was by vertical trawling up to $100 \mathrm{~m}$ deep, using a specific net $(20 \mu \mathrm{m}$ mesh size). After sample concentration, a formaldehyde solution was added (final concentration 2\%). The samples were then incorporated into the Phytoplankton Collection of the Federal University of Espírito Santo. Vertical profiles of salinity, temperature, and dissolved oxygen were obtained with a CTD and oximeter coupled to a rosette.
Sixteen sampling stations were arranged in two transects (Figure 1), the first comprising nine stations located over the seamount chain $\left(19^{\circ} \mathrm{S}\right)$, and the second, seven, most of which close to individual seamounts $\left(20^{\circ} \mathrm{S}\right)$. Distances between stations varied from 150 to $200 \mathrm{~km}$. One station was located at the southern end of the Abrolhos Bank (E26), another two on the continental slope (E23 and E27), and two more over the Vitória and Montague seamounts (E30 and E32, respectively). A further three were relatively close to the Jasur, Dogaressa and Columbia seamounts (E34, E36, and E38, respectively), and just one station close to Trindade Island (E40). The last seven were situated in deep offshore areas (E14, E15, E16, E17, E18, E19 and E20). The Geographical Information System (GIS) approach with Diva-Gis program v7.5 (http://www.diva-gis.org/), as well as a shape file from the Brazilian Institute of Geography and Statistics (IBGE) (http://mapas.ibge.gov. br/en/interativos/arquivos/downloads), were applied to assessing submarine bathymetry at the sampled sites.

Phytoplankton species diversity was analysed with an Olympus CX41 light microscope. Detected organisms were drawn, measured and photographed under 200x and 400x magnification (USB camera Bel IS500 5.0mp and TSView 7 images acquisition program). Digital images and drawings are available upon request. Three slides were observed for each sample using transect methodology under 100x magnification. In sequence, these taxa were identified with the appropriate bibliography (Kofoid 1905, Cupp 1943, Wood 1954, Abé 1967a, b, Balech 1967, 1971, 1979, Hallegraeff 1987, Balech 1988, Hernández-Becerril 1991, Fernández \& García 1998, Botes 2002, Polat \& Koray 2002, Gómez 2005, Koening \& Lira 2005, Tenenbaum et al. 2006, Haraguchi \& Odebrecht 2007, Islabão \& Odebrecht 2011, Garcia \& Odebrecht 2012, Okolodkov 2014).

The International Code of Nomenclature for Algae, Fungi and Plants (IAPT) was applied to taxonomic classification, and AlgaeBase (Guiry $\&$ Guiry 2015) to checking nomenclature. In sequence, a table was set up for indicating taxa occurrence per station, whereby percentages were obtained. This facilitated classification into categories as, (i) very common ( $\geq 70 \%$ of stations); (ii) common $(<70 \%$ and $\geq 30 \%$ ); (iii) uncommon $(<30 \%$ and $\geq 10 \%)$; and (iv) rare $(<10 \%)$.

Subsequently, the search focused on phytoplankton species already reported in marine waters of Brazil, with the aim of finding new records (Koening \& Lira 2005, Procopiak et al. 2006, Tenenbaum et al. 2006, 2007, Haraguchi \& Odebrecht, 2007, Sousa et al. 2008, Villac et al. 2008, Villac \& Tenenbaum 2010, Islabão \& Odebrecht 2011, Proença et al. 2011, Tiburcio et al. 2011, Garcia \& Odebrecht 2012, Jardim $\&$ Cardoso 2013, Menezes et al. 2015). All species synonyms were checked through AlgaeBase, in order to confirm the records in the publications consulted.

Hierarchical clustering methods are useful for evaluating species-composition correlations between stations, thereby revealing biogeographical connections with subjacent processes (Kreft \& Jetz 2010). The pvclust package v1.32 (Suzuki \& Shimodaira 2006), available in R program (http://www.r-project.org/), was applied in the present case. The Ward agglomerative method, based on the binary distance of taxonomic composition among stations, was employed for inferring hierarchical clustering. Statistical confidence of dendrogram nodes was defined by approximately unbiased (AU) support values that are less biased than the traditional bootstrap (Suzuki \& Shimodaira 2006). 


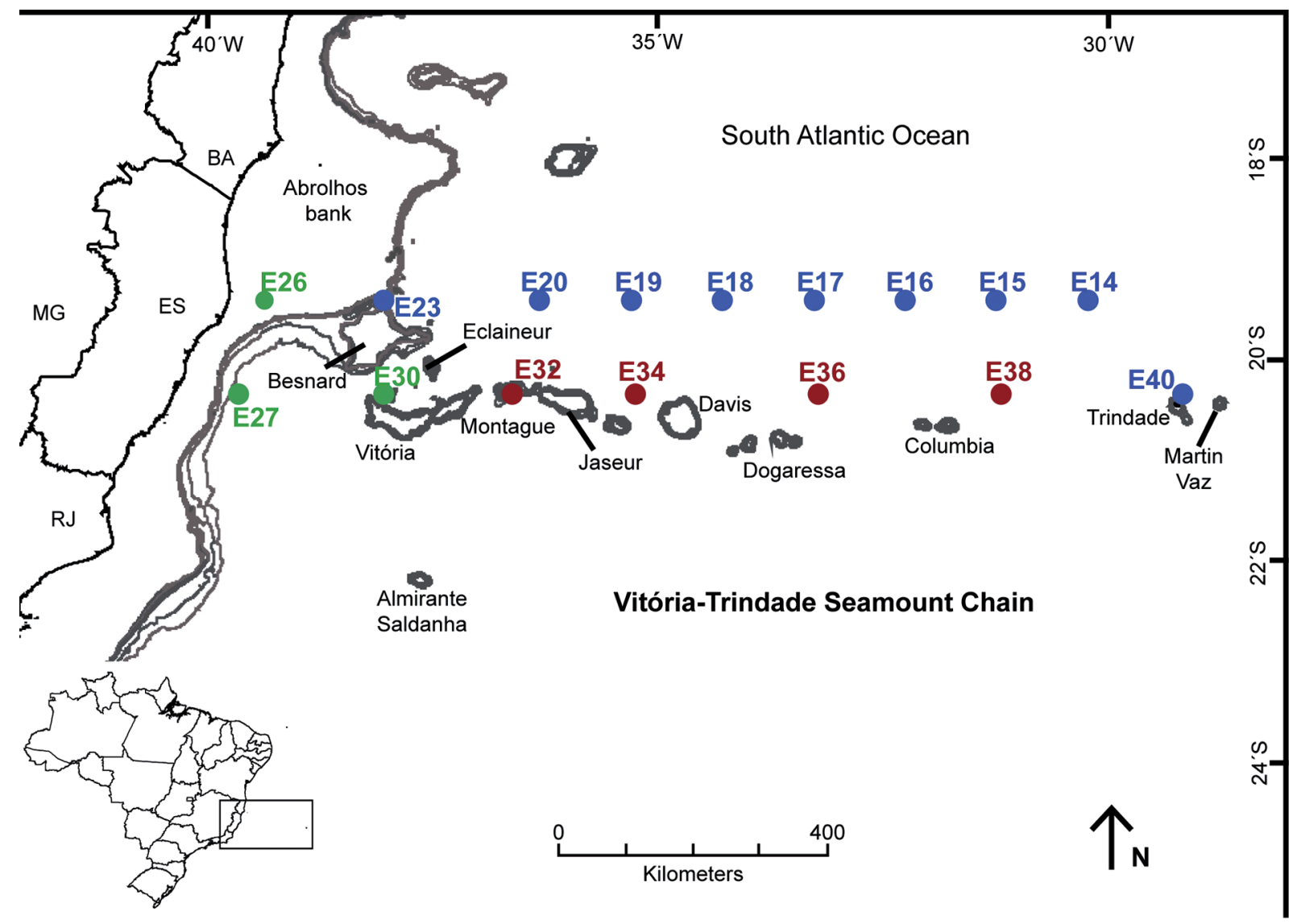

Figure 1. Map of the study area and sampling station sites. The colors of the stations are in accordance with Figure 5. Green stations are neritic, red, those closer to the Vitória-Trindade Seamount Chain, and bluethose located over deep offshore oceanic waters. The grey lines are isobaths (100- 2000 deep meters).

\section{Results}

The 175 identified infrageneric taxa of the micro and mesophytoplankton identified were distributed among four phyla, viz., Bacillariophyta L.S.Dillon, Cyanobacteria Stanier ex Cavalier-Smith, Dinophyta F.E.Round and Ochrophyta Cavalier-Smith in CavalierSmiith \& E.E.Chao (Table 1). The number of species registered per sample varied between 29 and 90 (average $54 \pm 15.59$ ).

The least represented phylum was Ochrophyta with only one species $(0.57 \%)$ of Dictyochophyceae P.C.Silva, Dictyocha fibula Ehrenberg, followed by Cyanobacteria, with two species of Trichodesmium Ehrenberg ex Gomont (1.14\%), Bacillariophyta, with 21 genera and 36 species (20.57\%), and finally, Dinophyta, the most numerous, with 24 genera and 131 infrageneric taxa $(74.85 \%)$ (Figure 2).

The family Rhizosoleniaceae De Toni contributed most to species diversity among the diatoms ( 9 species, 5.14\%). Chaetocerotaceae Ralfs in Pritchard came next (5, 2.86\%), followed by Coscinodiscaceae Kützing (4, 2.3\%), and finally, Asterolampraceae H.L.Smith (4, 2.3\%).

The order Gonyaulacales F.J.R.Taylor presented the highest number of identified taxa among all taxa $(62,35 \%)$, while its family Ceratiaceae Kofoid was the most diverse, due to the large number of Tripos Bory de St.-Vincent (45, 25.7\%). The second, as regards orders and families, were Dinophysiales Kofoid (40 taxa, 22.52\%) and Dinophysaceae Bütschli (30 taxa, 17.14\%). In the Dinophysaceae, Dinophysis Ehrenberg and Histioneis Stein were the most representative, comprising $11(6.3 \%)$ and $10(5.7 \%)$ species, respectively.

According to frequency of occurrence, 17 taxa (9\%) were very common, having been reported in more than $70 \%$ of the stations (Table 2 and Figure 3). All were dinoflagellates, ten of which Tripos (58.8\%). Ceratocorys horrida Stein and Tripos contrarius (Gourret) F.Gómez were observed in all the stations. The common category consisted of 55 (31\%) infrageneric taxa, two of which Cyanobacteria, five Bacillariophyta, and 48 Dinophyta, whereas the uncommon, 51 (29\%), was comprised of one Ochrophyta, 17 Bacillariophyta, and 33 Dinophyta. Among rare taxa, 50 (28.5\%) were recorded. Once again, dinoflagellates were the most diverse ( 31 species), followed by diatoms (19 species).

Thirty five new records of micro-and mesophytoplankton infrageneric taxa were found in the Vitória-Trindade Seamount Chain and continental shelf of Espírito Santo State, this including 12 new reports for Brazil (Table 3 and Figure 4). At a depth of 100 meters, and among stations, there was no significant change in environmental variables. Salinity varied between 37.39 and 37.055 (average 37.25) and temperatures 25.55 and $24.01^{\circ} \mathrm{C}$ (average $24.7^{\circ} \mathrm{C}$ ), thereby showing the predominance of tropical water in surface layers. Average dissolved oxygen was $4.64 \mathrm{mg} / 1$, this varing from 4.95 to $4.32 \mathrm{mg} / \mathrm{l}$. 
Lubiana, K.M.F. et al.

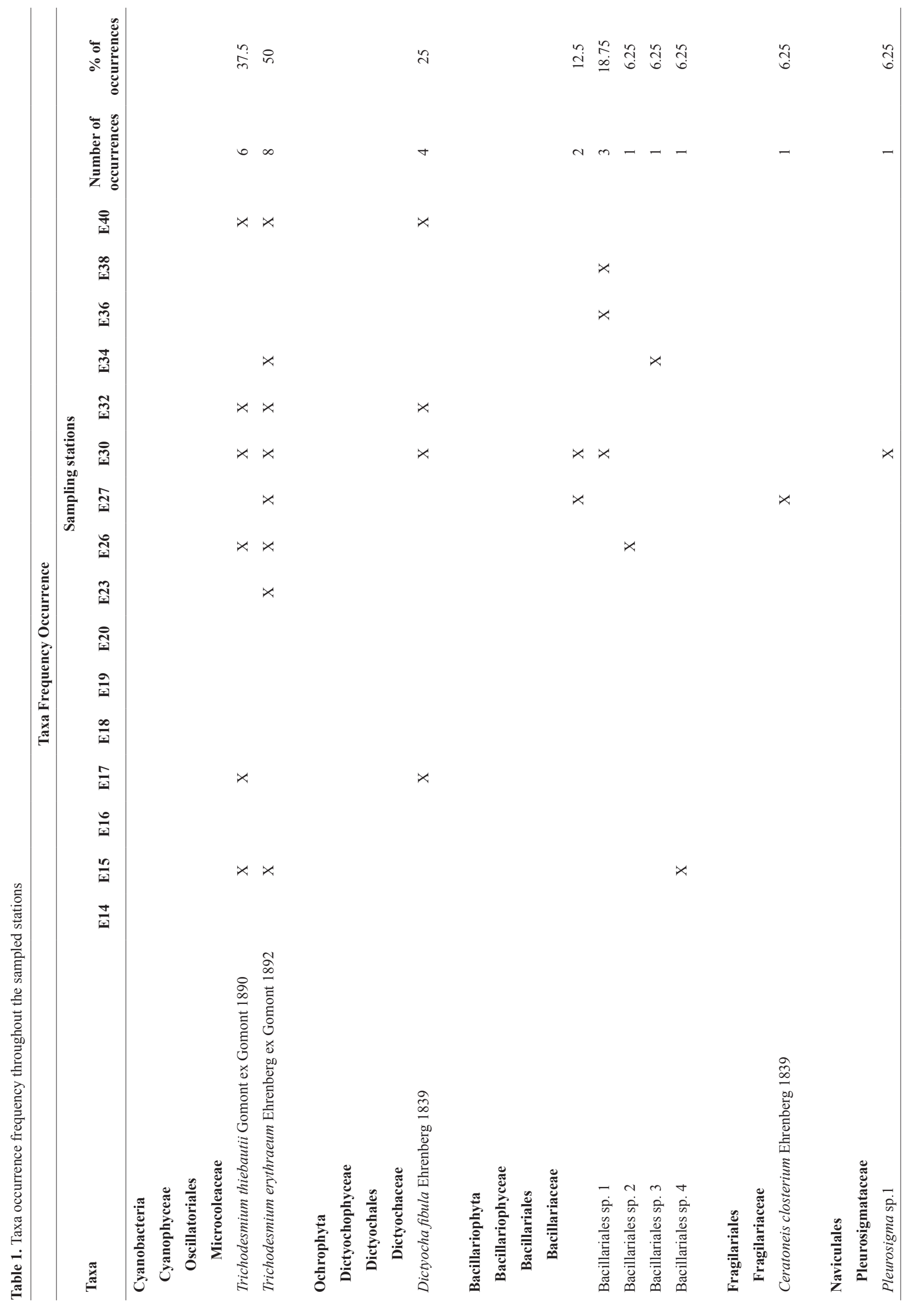


Phytoplankton at Vitória Trindade Seamount Chain

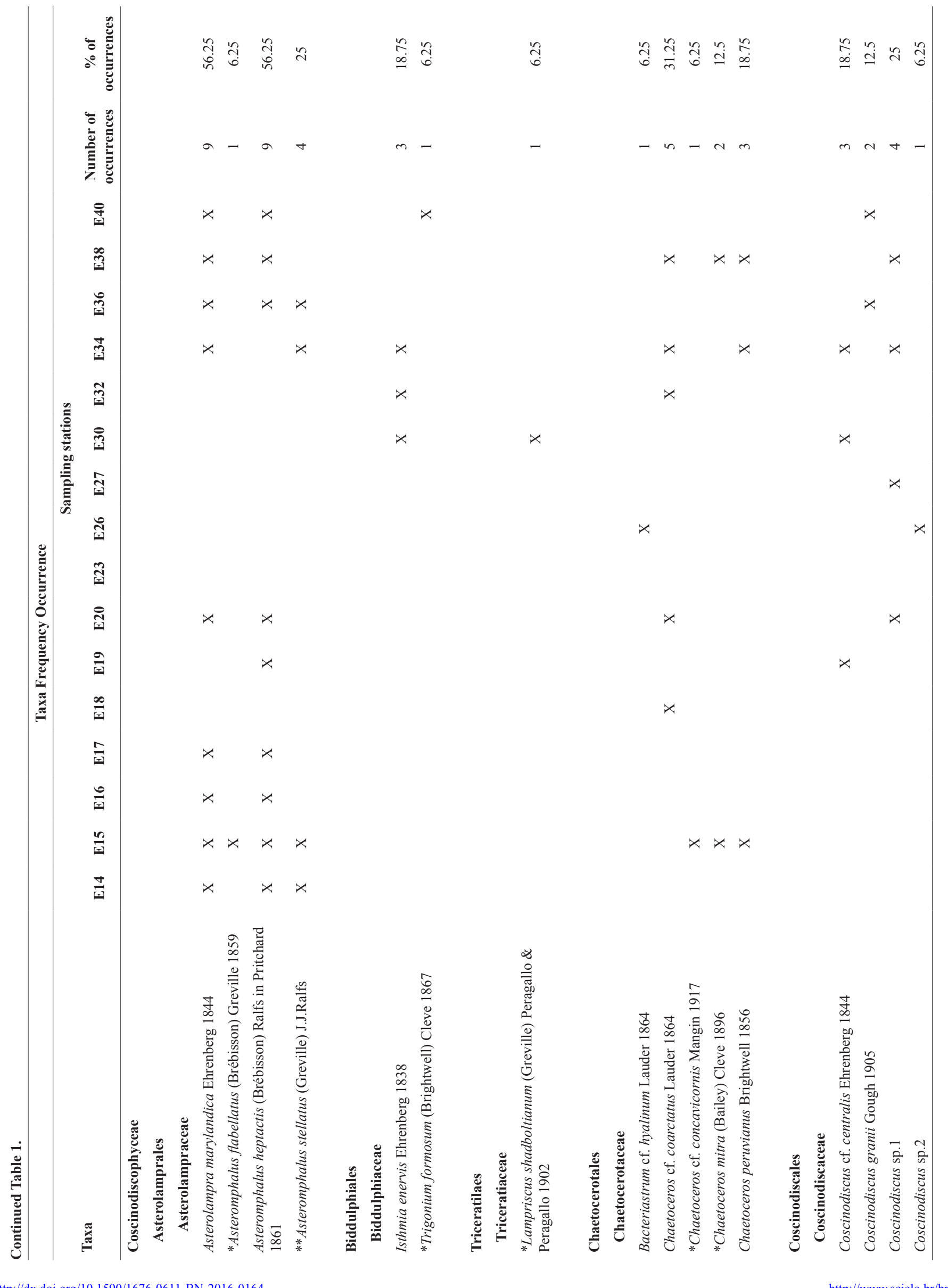


Lubiana, K.M.F. et al.

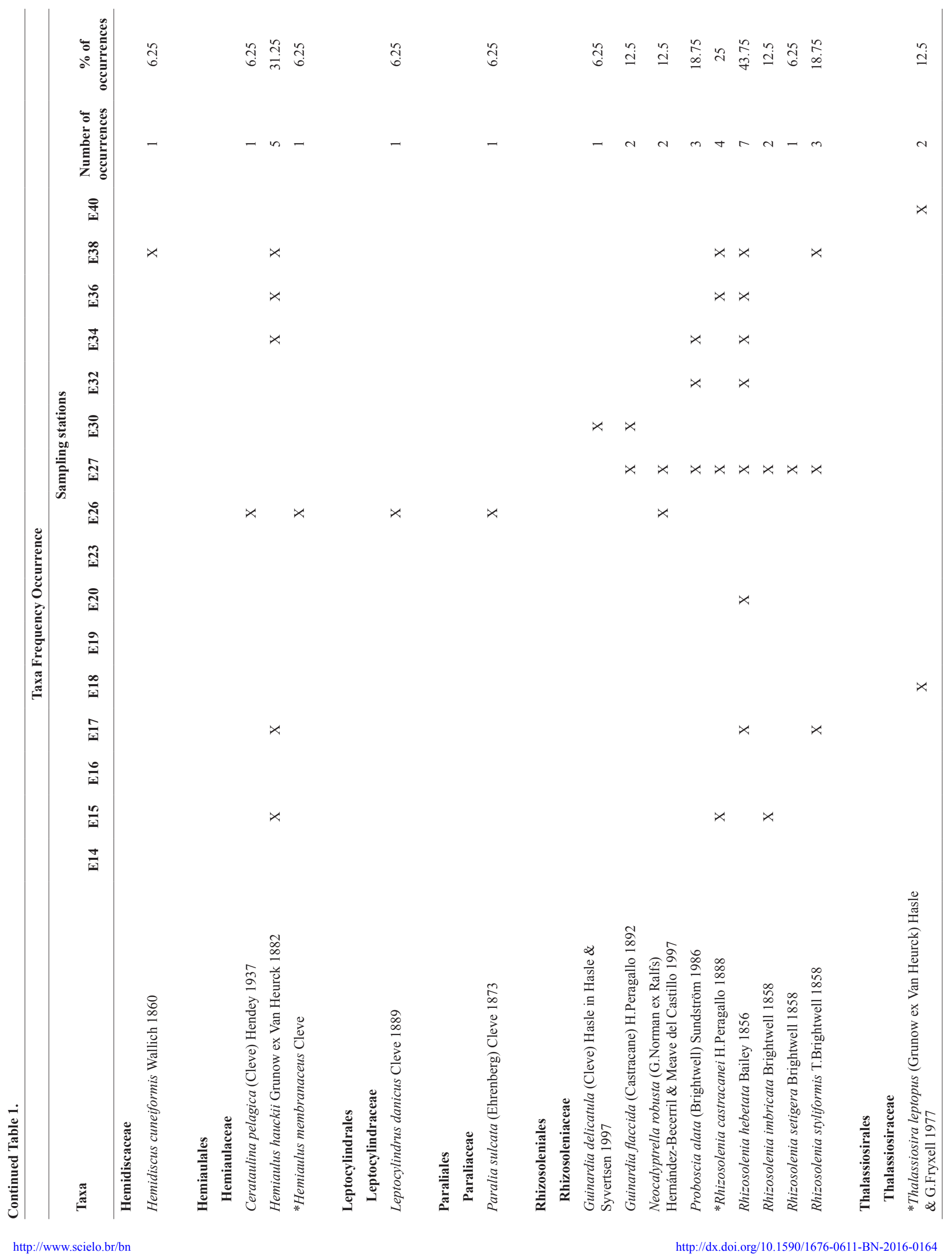


Phytoplankton at Vitória Trindade Seamount Chain

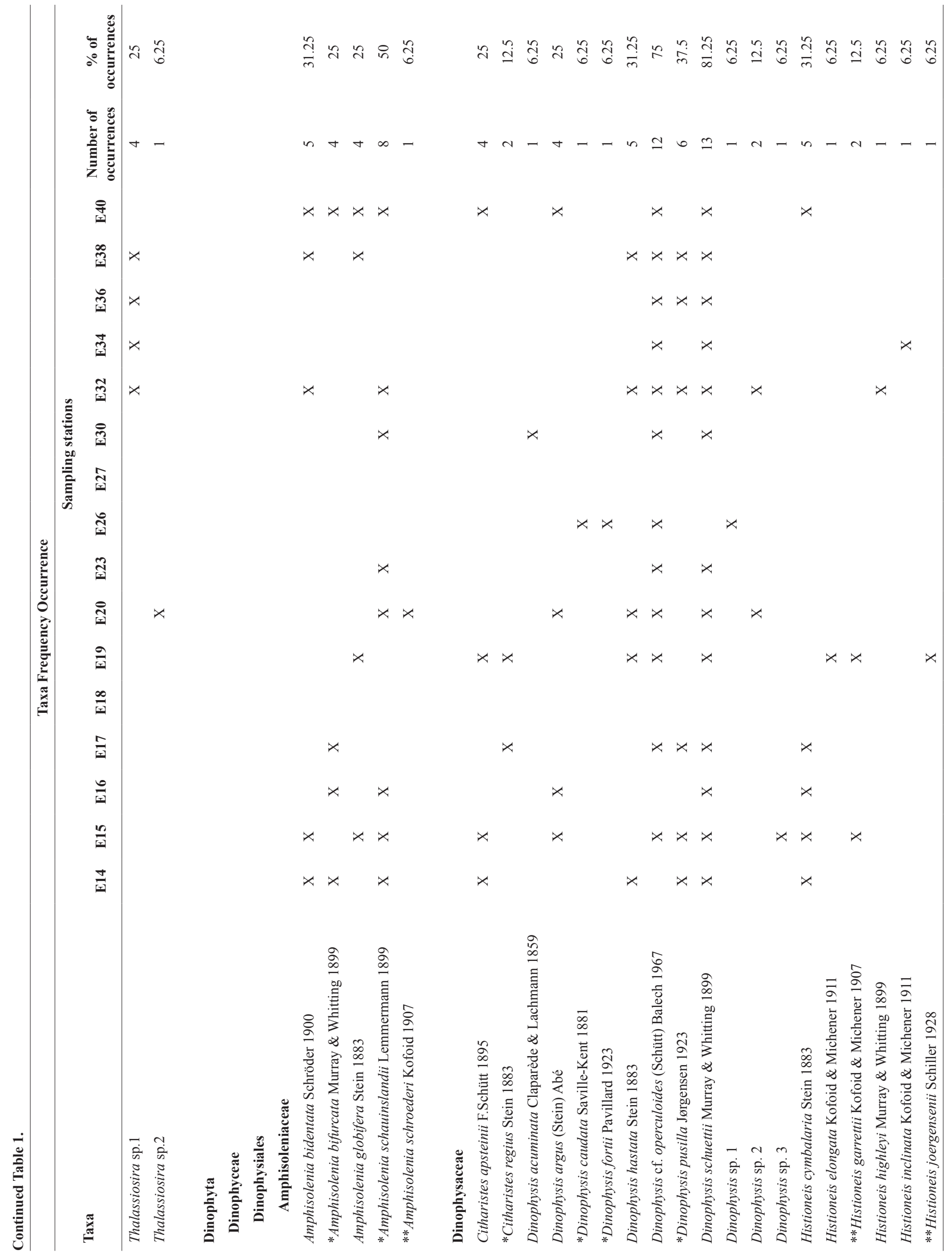


Lubiana, K.M.F. et al.

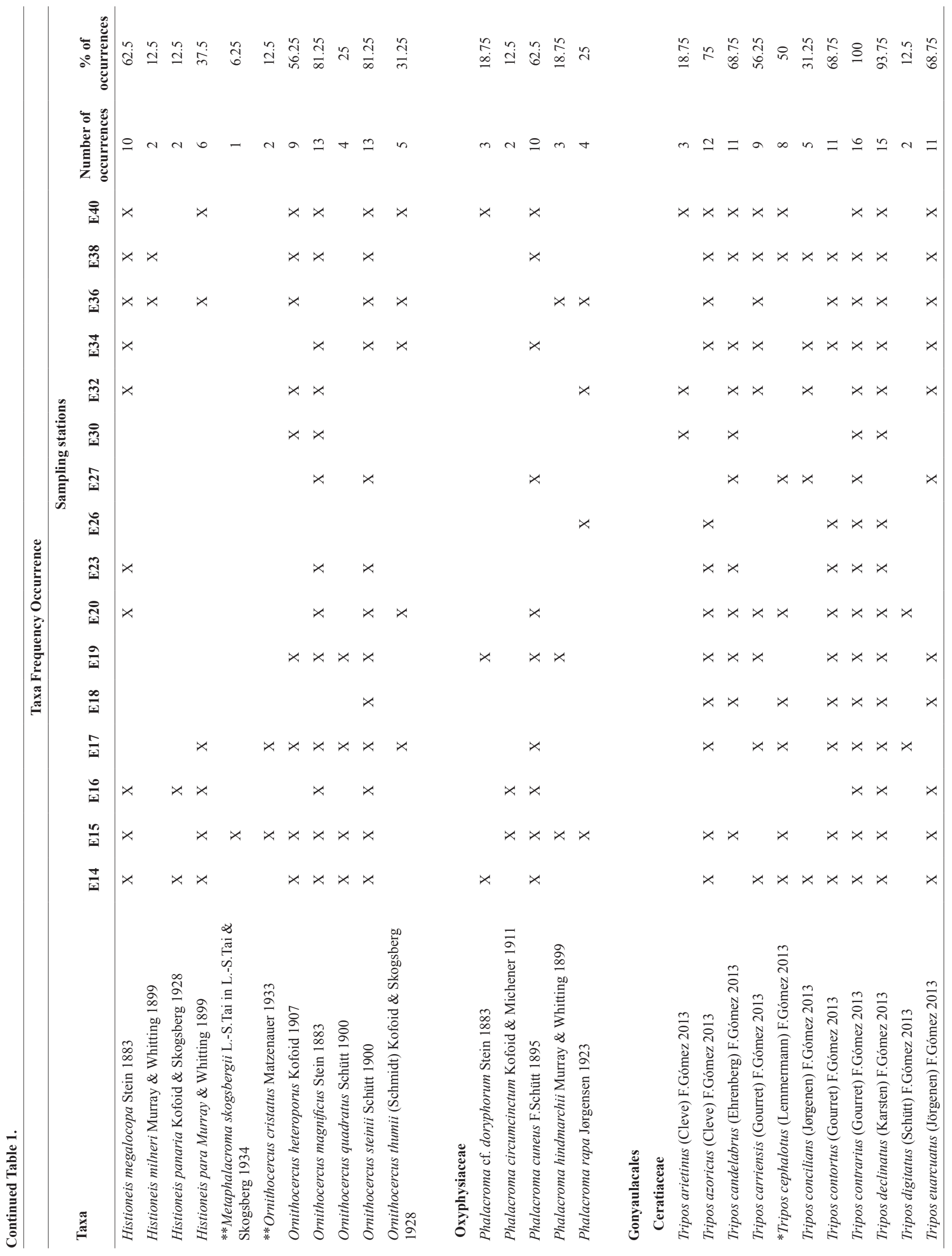


Phytoplankton at Vitória Trindade Seamount Chain

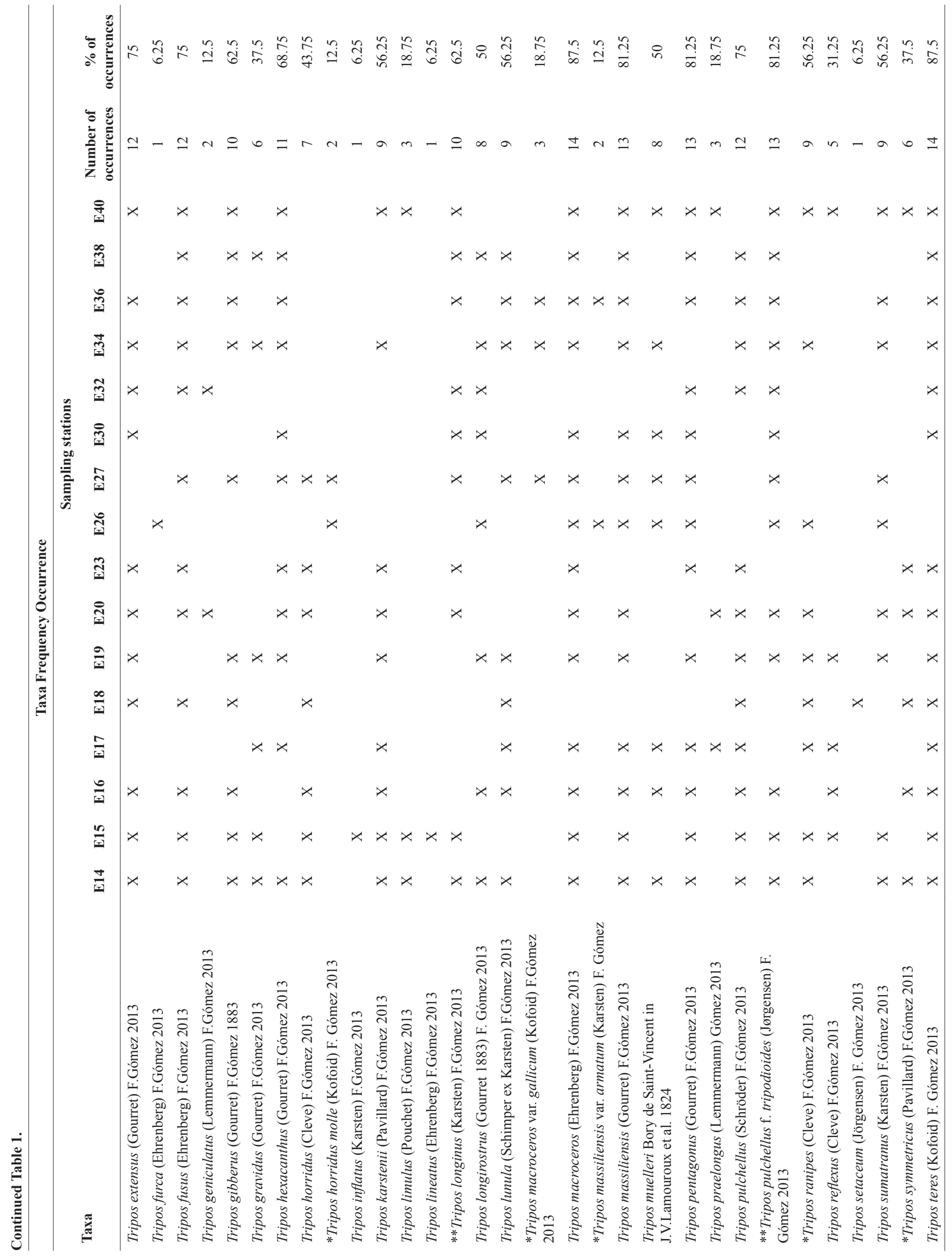


Lubiana, K.M.F. et al.

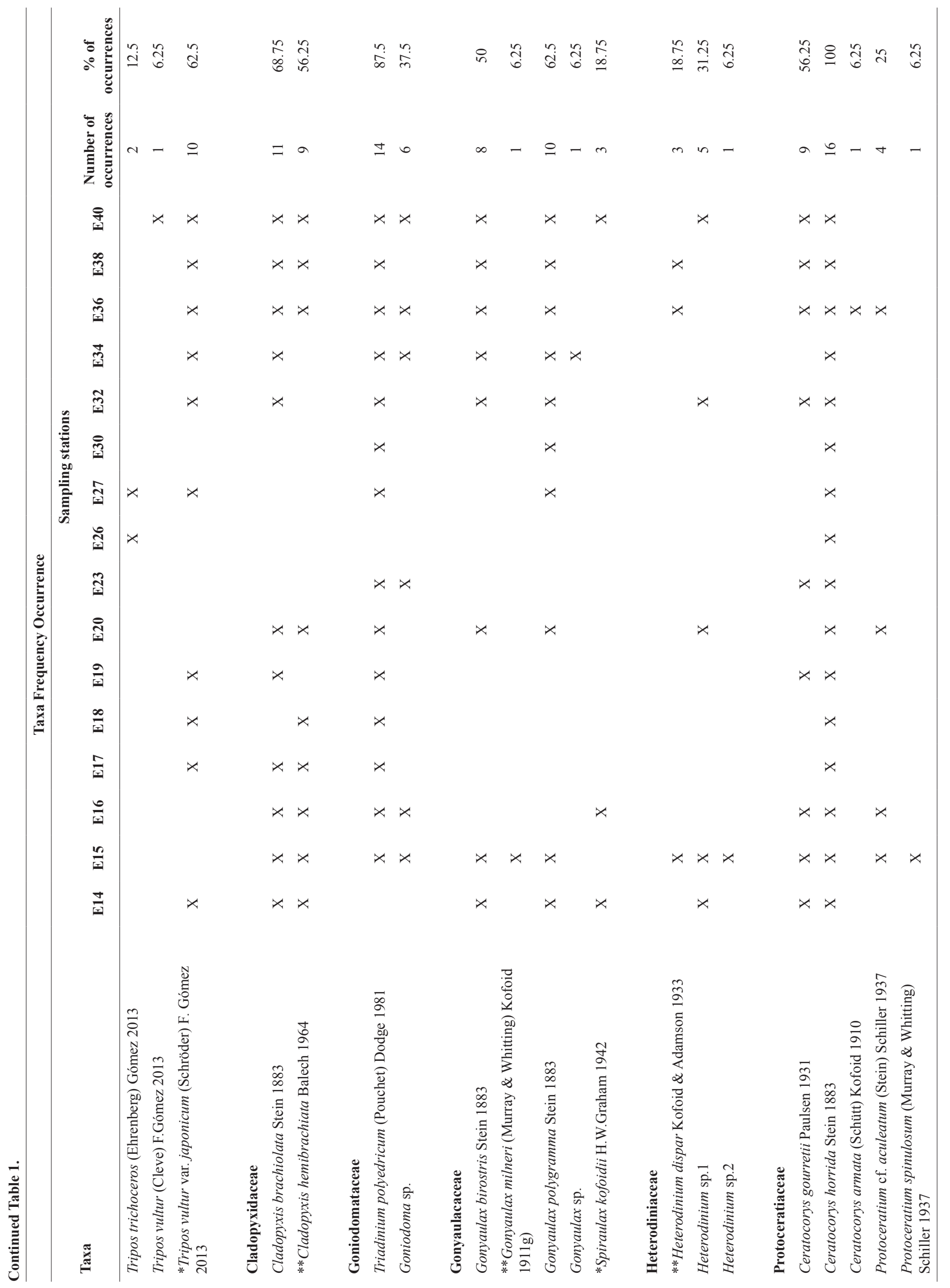


Phytoplankton at Vitória Trindade Seamount Chain

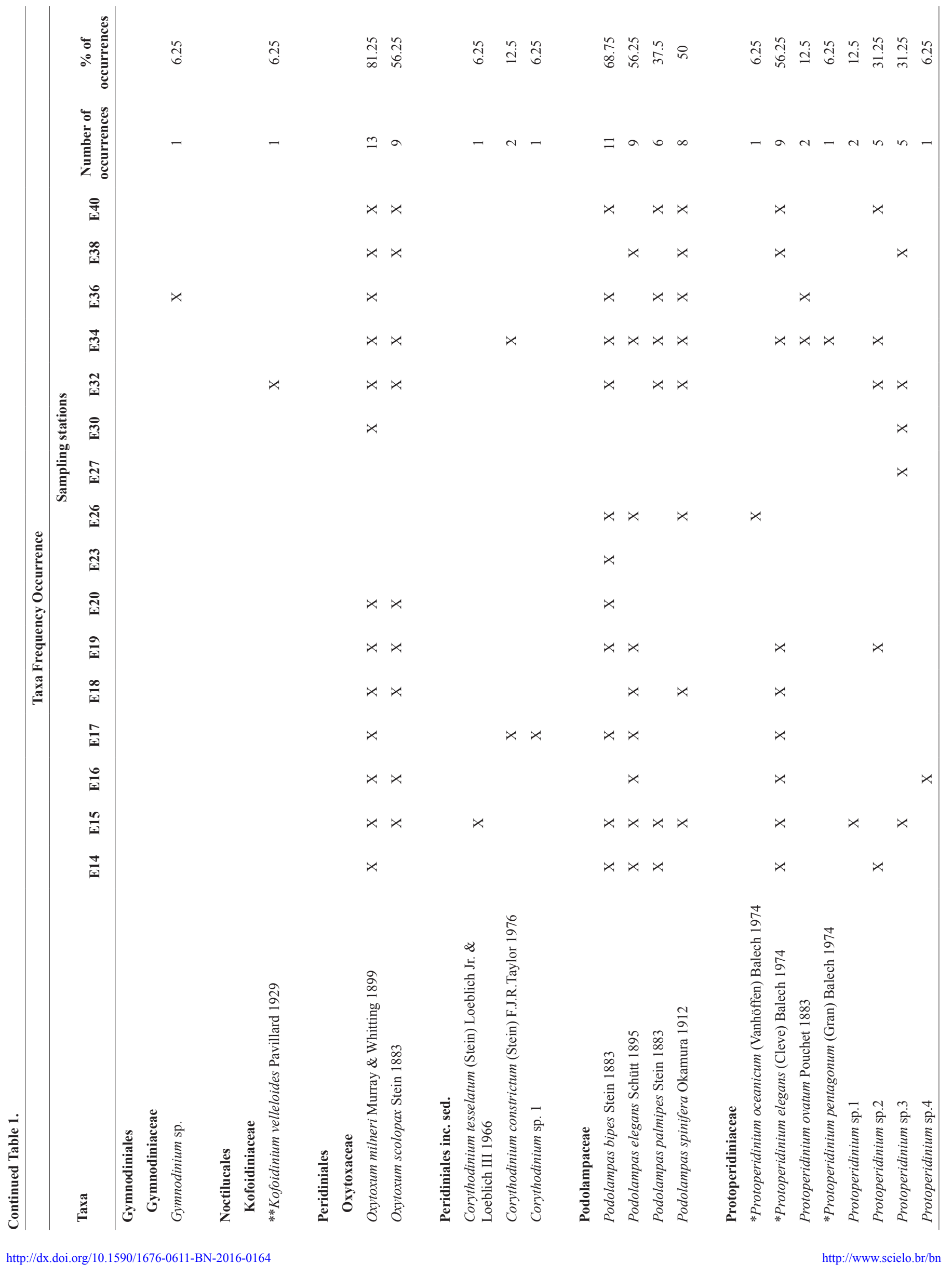


Lubiana, K.M.F. et al.

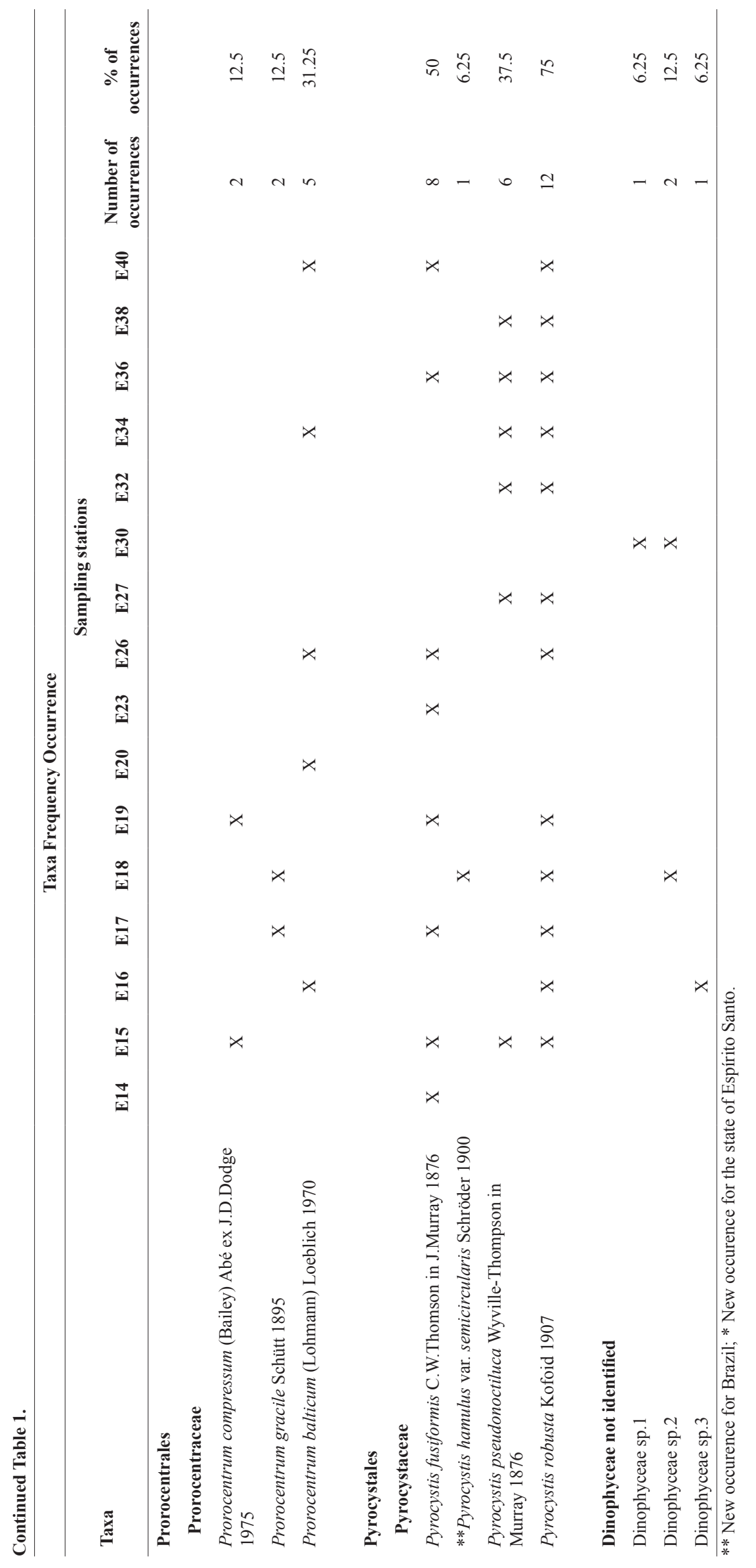




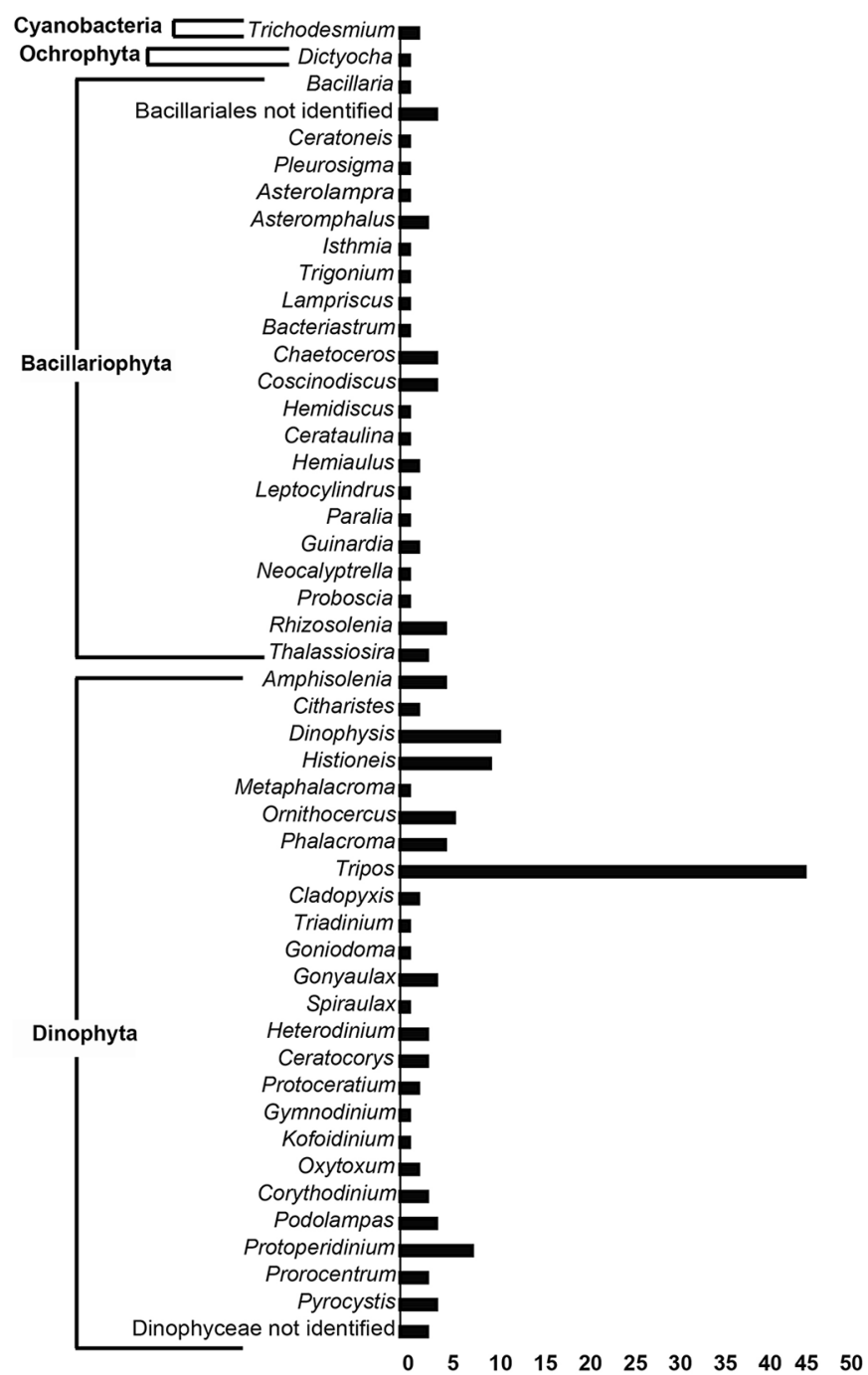

Figure 2. Genera biodiversity in the proximity of the Vitória-Trindade Seamount Chain. Four different phyla were identified. The number of species found for each genus is represented by bars.

Cluster analysis, by revealing differences in taxonomic composition among the various stations (Figure 5), facilitated their division into three main groups (Figure 1 and 5). The first, marked in green, and located closer to the continental shelf, were the most distant ( $71 \% \mathrm{AU}$ value), the second, in red, were near the Vitória-Trindade Seamount Chain $(81 \% \mathrm{AU})$, and the third, in blue, were in deep offshore areas $(81 \% \mathrm{AU})$.

\section{Discussion}

The high infrageneric diversity among the micro and mesophytoplankton observed corroborates previous findings for tropical oligotrophic regions (Hallegraeff \& Jeffrey 1984, Balech 1988). The high diversity of dinoflagellates collected in this area seems to be correlated with its preference for warm oligotrophic oceanic zones (Taylor et al 2007). Recently, the marine species of the genus Ceratium F.Schrank were renamed Tripos (Gómez et al. 2010, Gómez 2013) marine species of Ceratium (Dinophyceae, Alveolata. This presents, by
Table 2. Very common taxa in the stations ( $\geq 70 \%$ of occurrence).

\begin{tabular}{lcc}
\hline Taxa & $\begin{array}{c}\text { number } \\
\text { occurrence }\end{array}$ & $\begin{array}{c}\text { \% } \\
\text { occurrence }\end{array}$ \\
\hline Ceratocorys horrida Stein 1883 & 16 & 100 \\
Tripos contrarius (Gourret) F.Gómez 2013 & 16 & 100 \\
Tripos declinatus (Karsten) F.Gómez 2013 & 15 & 93.75 \\
Triadinium polyedricum (Pouchet) Dodge 1981 & 14 & 87.5 \\
Tripos macroceros (Ehrenberg) F.Gómez 2013 & 14 & 87.5 \\
Tripos teres (Kofoid) F. Gómez 2013 & 14 & 87.5 \\
Dinophysis schuettii Murray \& Whitting 1899 & 13 & 81.25 \\
Ornithocercus magnificus Stein 1883 & 13 & 81.25 \\
Ornithocercus steinii Schütt 1900 & 13 & 81.25 \\
Oxytoxum milneri Murray \& Whitting 1899 & 13 & 81.25 \\
Tripos massiliensis (Gourret) F.Gómez 2013 & 13 & 81.25 \\
Tripos pentagonus (Gourret) F.Gómez 2013 & 13 & 81.25 \\
Tripos pulchellus f. tripodioides (Jørgensen) & 13 & 81.25 \\
F. Gómez 2013 & 12 & 75 \\
Dinophysis cf. operculoides (Schütt) & 12 & 75 \\
Balech 1967 & & 75 \\
Tripos azoricus (Cleve) F.Gómez 2013 & 12 & \\
Tripos extensus (Gourret) F.Gómez 2013 & 12 & \\
Tripos fusus (Ehrenberg) F.Gómez 2013 & 13 & \\
\hline & & 75 \\
\hline
\end{tabular}

far, the highest number of infrageneric taxa. Incidentally, it was the most common genus in the samples collected. Furthermore, besides being more specious in tropical regions (Dodge 1993, Dodge \& Marshall 1994, Okolodkov \& Dodge 1996, Tunin-Ley \& Lemée 2013), it is usually the most diverse of the dinoflagellates (Taylor et al. 2007).

In an environment with low nutrient availability, nitrogen fixation is an important feature for ensuring fitness. Hence, the prevalence of the Cyanobacteria Trichodesmium can be understood. It is a diazotrophic organism that has been well documented both in the marine waters of Brazil (Satô et al. 1963, Brandini et al. 1997, Carvalho et al. 2008, Proença et al. 2009, Monteiro et al. 2010) and worldwide (Sellner 1997, Janson et al. 1999).

Several micro- and mesophytoplankton organisms accompany cyanobacteria nitrogen fixers. Richelia intracellularis J.Schmidt in Ostenfeld \& Schmidt is a diazotrophic cyanobacteria found in symbiotic relationship with certain diatoms, such as Rhizosolenia Brightwell (Padmakumaret al. 2010), Hemiaulus Heiberg (Kimor et al. 1978, Villareal 1994) and Chaetoceros Ehrenberg (Gómez et al. 2005). Furthermore, some oceanic dinoflagellates abide in symbiosis with unicellular diazotrophic bacteria, commonly found in certain genera of the non-photosynthetic Dinophysiales order, such as Histioneis, Ornithocercus Stein and Amphisolenia Stein (Foster et al. 2006, Farnelid et al. 2010). This corroborates our results on the high diversity of the above cited genera in the region of the Vitória-Trindade Seamount Chain.

When considering the lack of research on phytoplankton assemblages in Brazilian offshore waters, novel reports on infrageneric taxa can be expected. Other propitious factors could be $(i)$ the fluctuation of phytoplankton composition due to environmental changes, such as 

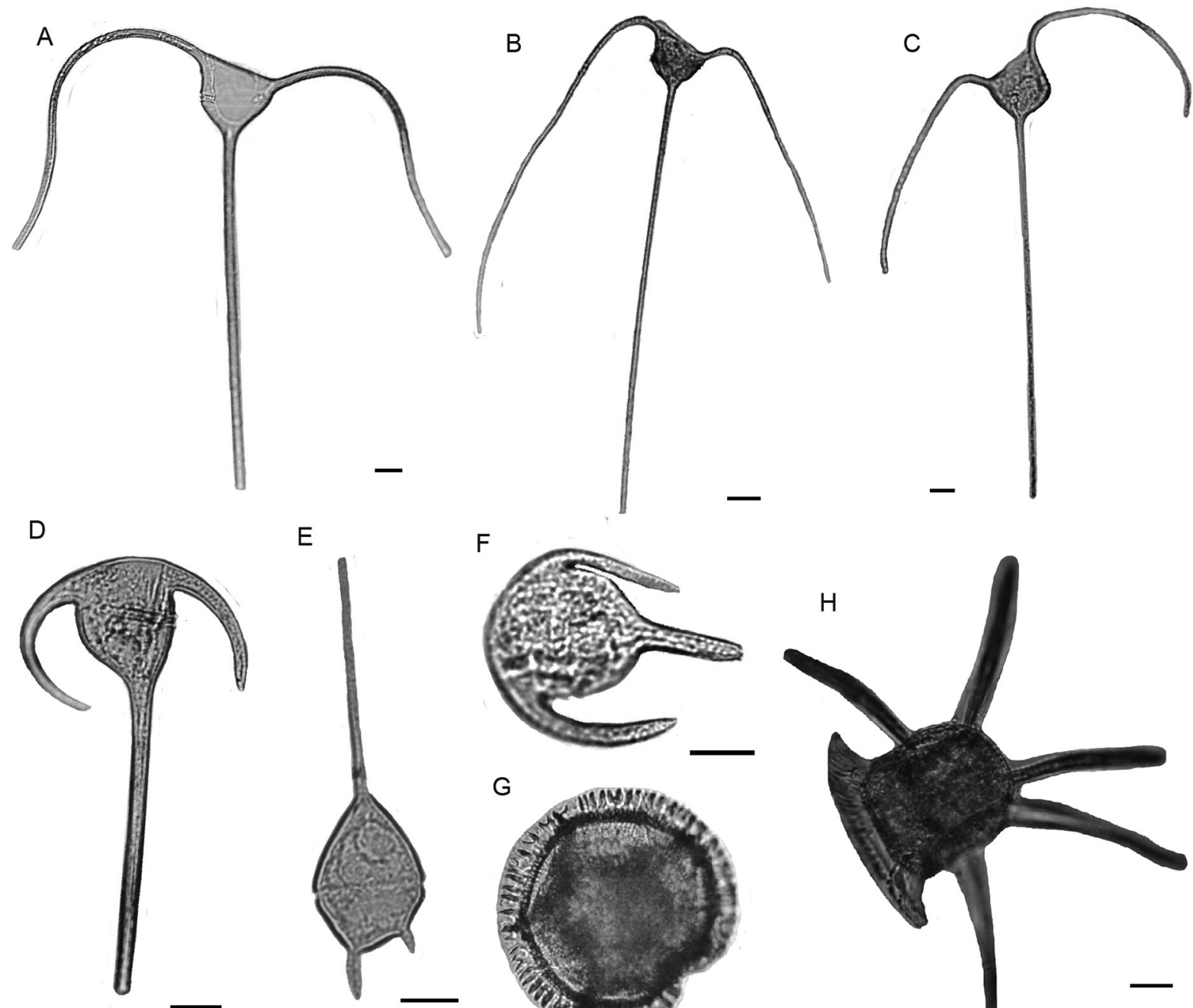

$\mathrm{E}$
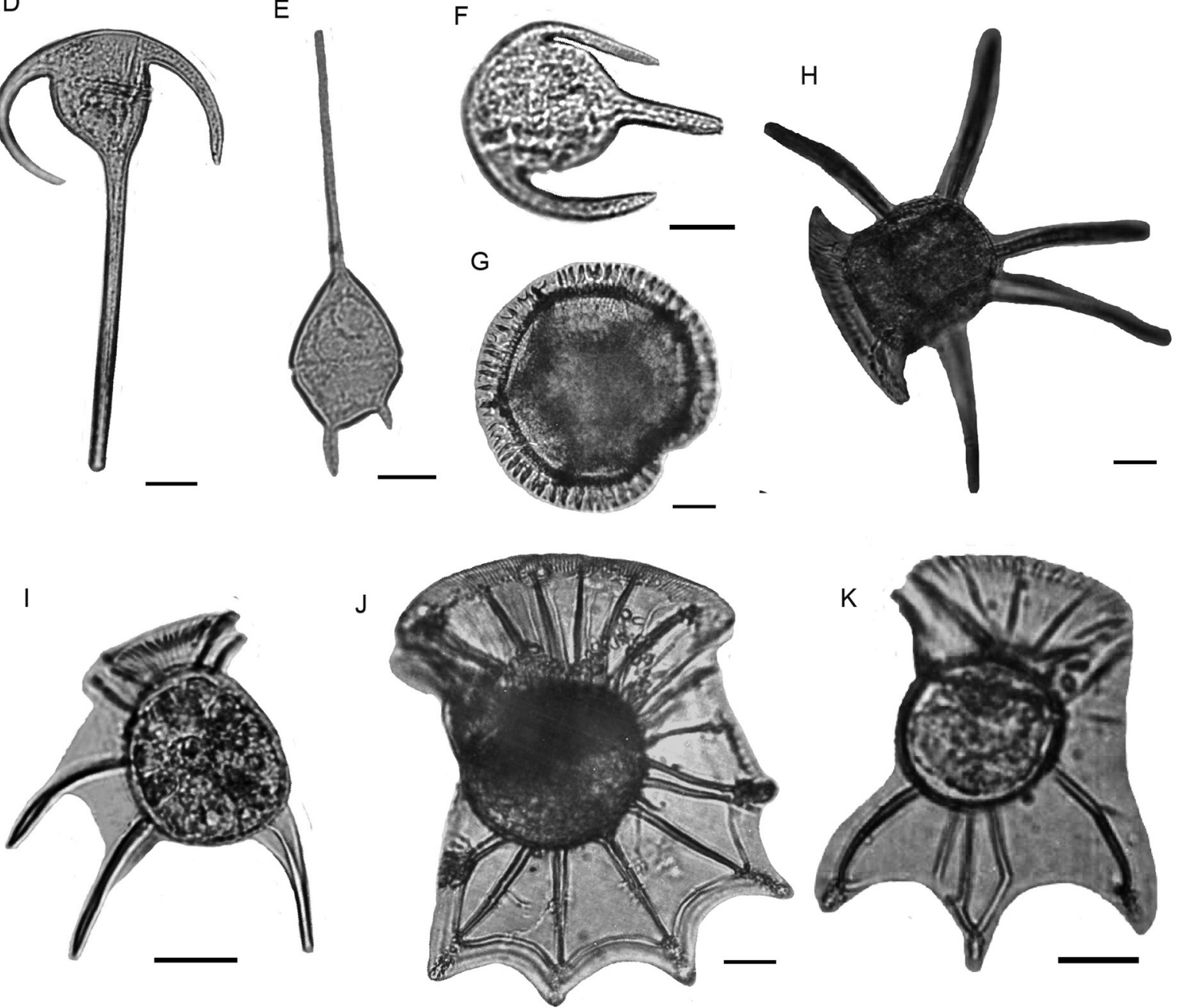

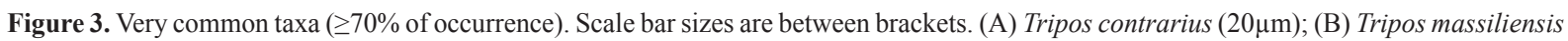

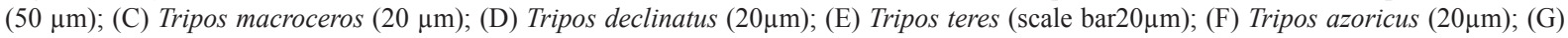
Triadinium polyedricum $(20 \mu \mathrm{m})$; (H) Ceratocorys horrida $(20 \mu \mathrm{m})$; (I) Dinophysis schuettii $(20 \mu \mathrm{m})$; (J) Ornithocercus steinii $(20 \mu \mathrm{m})$; (K) Ornithocercus magnificus $(20 \mu \mathrm{m})$. 
Table 3. New infrageneric taxa reports. New records for Brazil. (*) New records for waters of the Espírito Santo continental shelf and near the Vitória-Trindade seamount chain.

\begin{tabular}{|c|c|}
\hline Phylum & Species \\
\hline Bacillariophyta & Asteromphalus stellatus (Greville) J.J.Ralfs \\
\hline Dinophyta & Amphisolenia schroederi Kofoid 1907 \\
\hline Dinophyta & Cladopyxis hemibrachiata Balech 1964 \\
\hline Dinophyta & Heterodinium dispar Kofoid \& Adamson 1933 \\
\hline Dinophyta & Histioneis garrettii Kofoid \& Michener 1907 \\
\hline Dinophyta & Histioneis joergensenii Schiller 1928 \\
\hline Dinophyta & Kofoidinium velleloides Pavillard 1929 \\
\hline Dinophyta & $\begin{array}{l}\text { Metaphalacroma skogsbergii L.-S.Tai in L.-S.Tai \& } \\
\text { Skogsberg } 1934\end{array}$ \\
\hline Dinophyta & Ornithocercus cristatus Matzenauer 1933 \\
\hline Dinophyta & Pyrocystis hamulus var. semicircularis Schröder 1900 \\
\hline Dinophyta & Tripos longinus (Karsten) F.Gómez 2013 \\
\hline Dinophyta & Tripos pulchellus f. tripodioides (Jørgensen) F. Gómez 2013 \\
\hline Bacillariophyta & *Asteromphalus flabellatus (Brébisson) Greville 1859 \\
\hline Bacillariophyta & *Chaetoceros cf. concavicornis Mangin 1917 \\
\hline Bacillariophyta & *Chaetoceros mitra (Bailey) Cleve 1896 \\
\hline Bacillariophyta & *Rhizosolenia castracanei H.Peragallo 1888 \\
\hline Bacillariophyta & *Hemiaulus membranaceus Cleve \\
\hline Bacillariophyta & $\begin{array}{l}\text { *Lampriscus shadboltianum (Greville) Peragallo \& } \\
\text { Peragallo } 1902\end{array}$ \\
\hline Bacillariophyta & $\begin{array}{l}\text { *Thalassiosira leptopus (Grunow ex Van Heurck) Hasle } \\
\text { \& G.Fryxell } 1977\end{array}$ \\
\hline Bacillariophyta & *Trigonium formosum (Brightwell) Cleve 1867 \\
\hline Dinophyta & *Amphisolenia bifurcata Murray \& Whitting 1899 \\
\hline Dinophyta & *Amphisolenia schauinslandii Lemmermann 1899 \\
\hline Dinophyta & *Citharistes regius Stein 1883 \\
\hline Dinophyta & *Dinophysis caudata Saville-Kent 1881 \\
\hline Dinophyta & *Dinophysis fortii Pavillard 1923 \\
\hline Dinophyta & *Dinophysis pusilla Jørgensen 1923 \\
\hline Dinophyta & *Protoperidinium elegans (Cleve) Balech 1974 \\
\hline Dinophyta & *Protoperidinium oceanicum (Vanhöffen) Balech 1974 \\
\hline Dinophyta & *Protoperidinium pentagonum (Gran) Balech 1974 \\
\hline Dinophyta & *Spiraulax kofoidii H.W.Graham 1942 \\
\hline Dinophyta & *Tripos cephalotus (Lemmermann) F.Gómez 2013 \\
\hline Dinophyta & *Tripos macroceros var. gallicum (Kofoid) F.Gómez 2013 \\
\hline Dinophyta & *Tripos massiliense var. armatum (Karsten) F. Gómez \\
\hline Dinophyta & *Tripos symmetricus (Pavillard) F.Gómez 2013 \\
\hline Dinophyta & *Tripos vultur var. japonicum (Schröder) F. Gómez 2013 \\
\hline
\end{tabular}

seasonality, (ii) misidentification of species, and (iii) very low density of some species, thereby precluding their perception in previous studies.

There was little variation in environmental data. In temperature, although the highest range, the values varied between $1.5^{\circ} \mathrm{C}$. Considering the variables obtained, the conditions in the study area could be considered stable. Therefore, it was impossible to associate the differences in phytoplankton composition with the data obtained.
Maybe, quantifying and qualifying nutrients could give a better indication for the findings.

Cluster analysis indicated how close the stations were in terms of taxonomic composition, and also that geographic distances between the stations were correlated with species composition: the closer the stations to one another, the more species they shared in common. The same association was found in a biogeographic study of Tripos (Dodge 1993). Furthermore, the grouping of stations into three different clusters could be justified by the high number of uncommon and rare taxa (101 taxa, 57.5\%), thereby indicating that many species are not extensively disposed. It was noteworthy that the three clusters seemed to be correlated to continental closeness and seafloor bathymetry. This is in accordance with previous findings, whereby neritic species assemblage differs from the oceanic (Dodge 1993, Raine et al. 2002, Taylor et al. 2007), and seamounts can influence species composition and density (Genin \& Boehlert 1985, Pitcher et al. 2007).

The high micro- and mesophytoplankton species diversity is apparently related to tropical oligotrophic oceanic zones. Several of the organisms identified were either mixotrophic, or maintained a symbiotic association with diazotrophic bacteria. The results are important in defining micro-and mesophytoplankton diversity, especially among the dinoflagellates. The numerous new infrageneric taxa reported for the marine waters off Espírito Santo State, and Brazil as a whole, indicate the importance of inventory surveys, and the lack of studies of phytoplankton assemblages. Bathymetric dissemblance in the area studied could be associated with differences in species composition. Neritic stations formed a distinct cluster from the oceanic and seamount. Furthermore, geographic distances between stations possibly exert an influence on species distribution. Further studies of phytoplankton should be extended to the area, especially those of other phytoplankton size-fractions, such as pico- and nanoplankton. The application of other methodologies, such as cultures, metabarcoding and metagenomics, would be useful for enhance the knowledge about the community.

\section{Acknowledgements}

We wish to thank FAPES (Fundação de Amparo à Pesquisa do Espírito Santo) for the scholarship ceded to Karoline Magalhães Ferreira Lubiana (44576170/2009), and also Caio C. M. Freire for helping with statistical analysis.

\section{References}

ABÉ, T.H. 1967a. The armoured Dinoflagellata: II. Prorocentridae and Dinophysidade (C)- Ornithocercus, Histioneis, Amphisolenia and others. Publ. Seto Mar. Biol Lab. 15(2):79-116.

ABÉ, T.H. 1967b. The armoured Dinoflagellata: II. Prorocentridae and Dinophysidae (B)- Dinophysis and its allied genera. Publ. Seto. Mar. Biol. Lab. 15(1): 37-78.

ALMEIDA, F. 2006. Ilhas oceânicas brasileiras e suas relações com a tectônica atlântica. Terrae Didat. 2(1): 3-18.

BALECH, E. 1967. Dinoflagelados Nuevos o Interesantes del Golfo de Mexico y Caribe. Rev. Mus. Argent. Cienc. Nat. 3(3): 1-126.

BALECH, E. 1971. Microplancton del Atlantico Ecuatorial Oeste (Equalant II). Servicio Hidrografico Naval Buenos Aires, Argentina, v. 654, p. 1-199.

BALECH, E. 1979. Dinoflagelados campaña oceanografica Argentina Islas Orcadas 0675. Talleres Graficos del S. H. N. Buenos Aires. 
A

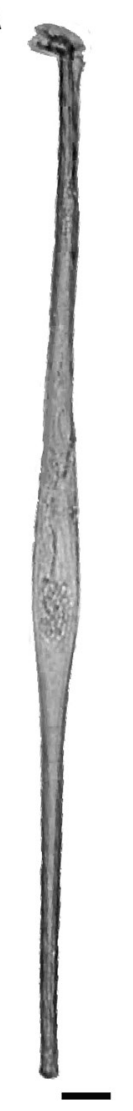

C
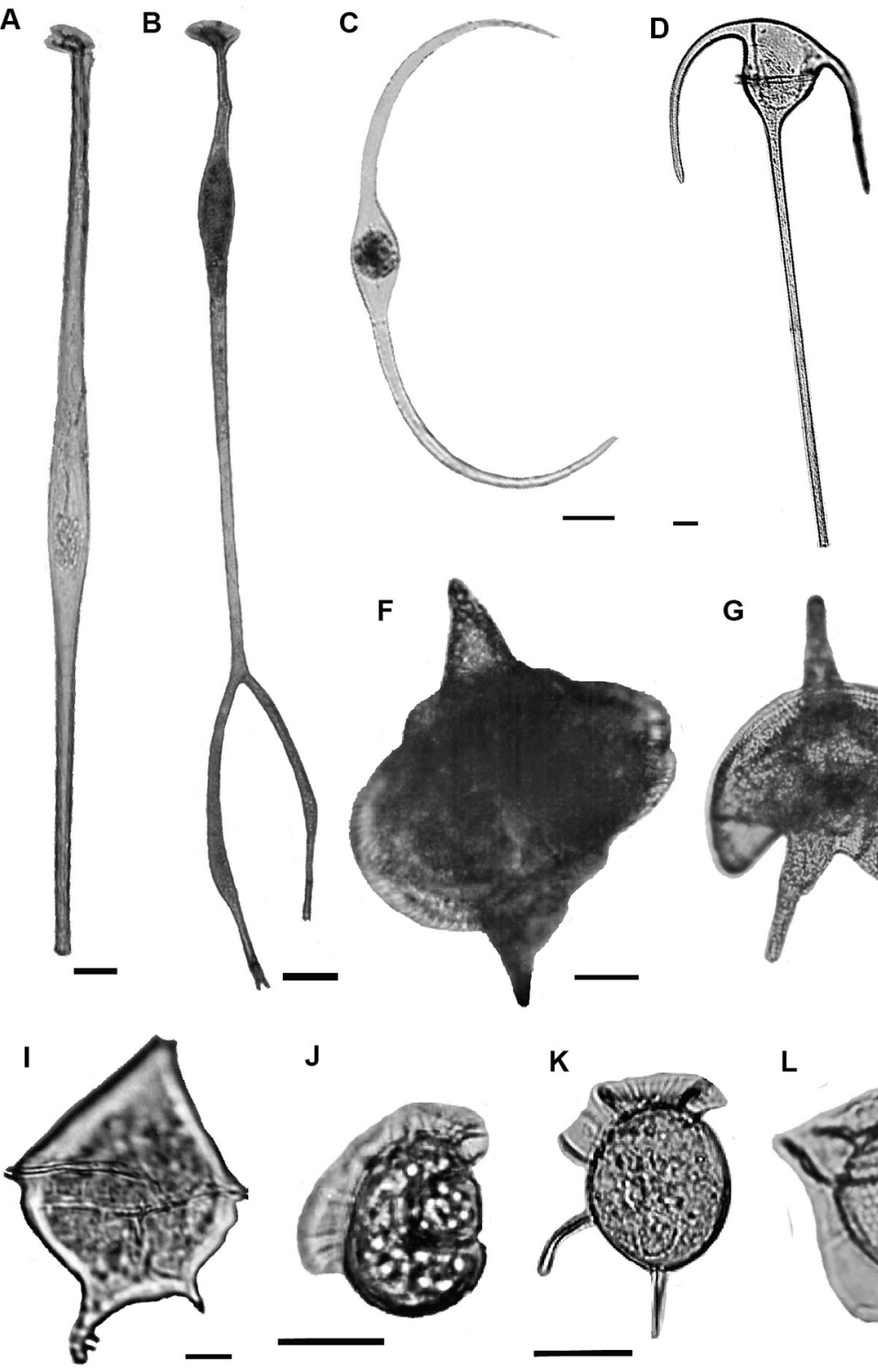

J

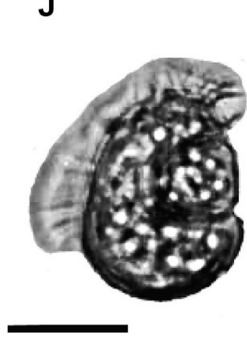

\begin{abstract}
K
\end{abstract}

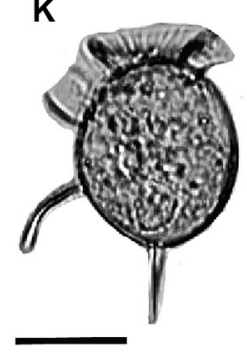

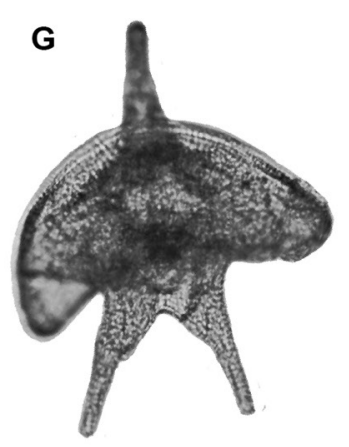

$\mathbf{L}$

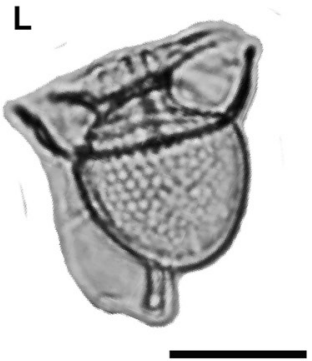

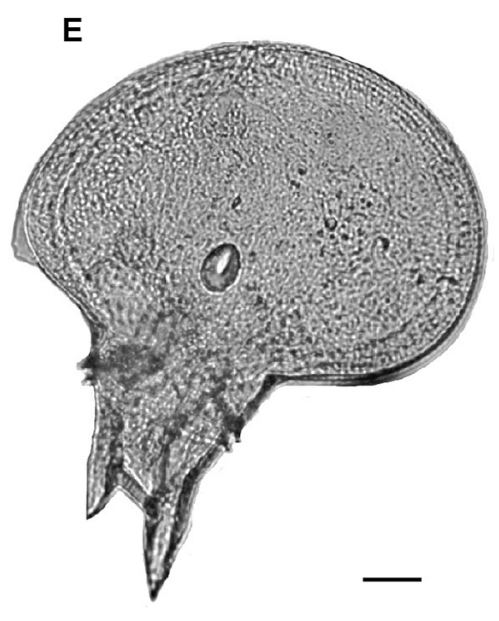

H

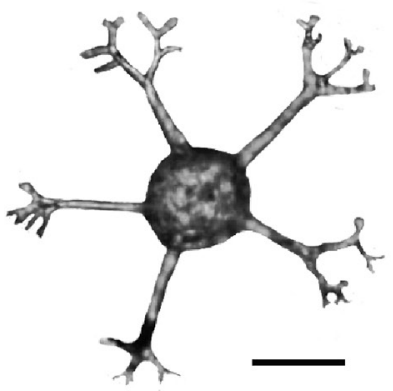

Figure 4. Some of the new records for marine waters of Brazil and Espírito Santo State $\left({ }^{*}\right)$. Scale bar sizes are between brackets. (A)*Amphisolenia schauinslandii $(20 \mu \mathrm{m})$; (B) *Amphisolenia bifurcata $(10 \mu \mathrm{m})$; (C) Pyrocystis hamulus var. semicircularis $(50 \mu \mathrm{m})$; (D) Tripos pulchellus $\mathrm{f}$. tripodioides $(20 \mu \mathrm{m}) ;(\mathrm{E}) *$ Tripos cephalotus $(20 \mu \mathrm{m}) ;(\mathrm{F}) *$ Spiraulax kofoidii $(20 \mu \mathrm{m}) ;(\mathrm{G}) *$ Protoperidinium elegans $(20 \mu \mathrm{m}) ;(\mathrm{H})$ Cladopyxis hemibrachiata $(20 \mu \mathrm{m})$; (I) Heterodinium dispar $(10 \mu \mathrm{m}) ;(\mathrm{J}) *$ Citharistes regius $(20 \mu \mathrm{m}) ;(\mathrm{K}) *$ Dinophysis pusilla $(20 \mu \mathrm{m})$; (L) Histioneis garrettii $(20 \mu \mathrm{m}) ;(\mathrm{M})$ Histioneis joergensenii $(20 \mu \mathrm{m})$

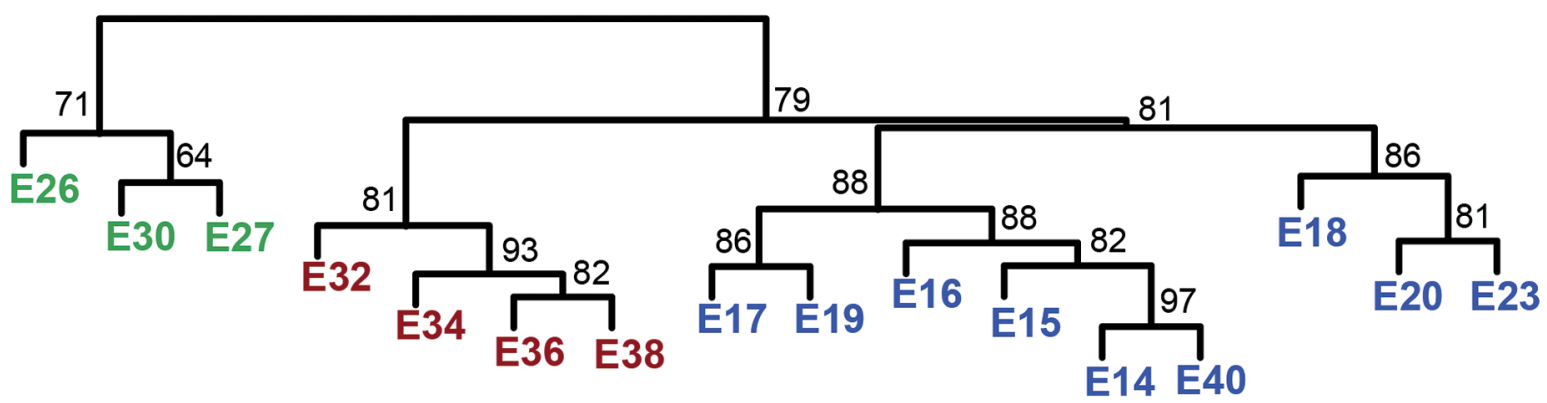

Figure 5. Hierarchical cluster dendrogram representing binary distances between stations according to phytoplankton species composition. Green represents the neritic group, red those closer to the seamounts, and blue those in deep offshore areas. 
BALECH, E. 1988. Los Dinoflagelados Del Atlantico Sudoccidental. 1st ed. Publ. Espec. Inst. Esp. Oceanogr. Madrid.

BARTON, A.D., DUTKIEWICZ, S., FLIERL, G., BRAGG, J. \& FOLLOWS, M.J. 2010. Patterns of diversity in marine phytoplankton. Science. 327: 1509-1511.

BOTES, L. 2002. Phytoplankton Identification Catalogue: Saldanha Bay, South Africa, April 2001. GloBallast. London.

BRANDINI, F.P., LOPES, R.M., GUTSEIT, K.S., SPACH, H.L. \& SASSI, R. 1997. Planctonologia na plataforma continental do Brasil: diagnose e revisão bibliográfica. Fundação de Estudos do Mar- FEMAR. Rio de Janeiro.

CARVALHO, M., GIANESELLA, S.M.F. \& SALDANHA-CORRÊA, F.M.P 2008. Trichodesmium erythraeum bloom on the continental shelf off Santos, Southeast Brazil. Braz. J. Oceanogr. 56(4): 307-311.

CUPP, E.E. 1943. Marine plankton diatoms of the West Coast of North America University of California Press, Berkeley.

DODGE, J.D. 1993. Biogeography of the planktonic dinoflagellate Ceratium in the Western Pacific. Korean J. Phycol. 8(2): 109-119.

DODGE, J.D. \& MARSHALL, H.G. 1994. Biogeographic analysis of the armored planktonic dinoflagellate Ceratium in the North Atlantic and adjacent seas. J. Phycol. 30(6): 905-922.

FARNELID, H., TARANGKOON, W., HANSEN, G., HANSEN, P.J. \& RIEMANN, L. 2010. Putative N2-fixing heterotrophic bacteria associated with dinoflagellate-cyanobacteria consortia in the low-nitrogen Indian Ocean. Aquat. Microb. Ecol. 61(2): 105-117.

FERNÁNDEZ, C.E. \& GARCÍA, C.B. 1998. The dinoflagellates of the genera Ceratium and Ornithocercus collected in the Golfo of Salamanca, Colombian Caribbean Sea. Rev. Acad. Colomb. Cienci. 22(85): 539-559.

FIELD, C.B. 1998. Primary production of the biosphere: integrating terrestrial and oceanic components. Science. 281(5374): 237-240.

FOSTER, R. A., CARPENTER, E.J. \& BERGMAN, B. 2006. Unicellular cyanobionts in open ocean dinoflagellates, radiolarians, and tintinnids: ultrastructural characterization and immuno-localization of phycoerythrin and nitrogenase. J.Phycol. 42(2): 453-463.

GAETA, S.A., LORENZZETTI, J.A., MIRANDA, L.B. de, SUSINI-RIBEIRO, S.M.M., POMPEU, M. \& ARAUUJO, C.E.S.1999. The Vitória Eddy and its relation to the phytoplankton biomass and primary productivity during the austral fall of 1995. Arch. Fisch. Mar. Res. 47(2/3): 253-270.

GARCIA, M. \& ODEBRECHT, C. 2012. Remarks on the morphology and distribution of some rare centric diatoms in Southern Brazilian continental shelf and slope waters. Braz. J. Oceanog. 60(4): 415-427.

GENIN, A. \& BOEHLERT, G.W. 1985. Dynamics of temperature and chlorophyll structures above a seamount: an oceanic experiment. J. Mar. Res. 43(4): 907-924.

GÓMEZ, F., 2005. Histioneis (Dinophysiales, Dinophyceae) from the western Pacific Ocean. Bot. Mar. 48(5-6): 421-425.

GÓMEZ, F., 2013. Reinstatement of the dinoflagellate genus Tripos to replace Neoceratium, marine species of Ceratium (Dinophyceae, Alveolata). CICIMAR Océanides..28(1): 1-22.

GÓMEZ, F., FURUYA, K.\& TAKEDA, S. 2005. Distribution of the cyanobacterium Richelia intracellularis as an epiphyte of the diatom Chaetoceros compressus in the western Pacific Ocean. J. Plankton Res. 27(4): 323-330.

GÓMEZ, F., MOREIRA, D. \& LÓPEZ-GARCÍA, P. 2010. Neoceratium gen. nov., a new genus for all marine species currently assigned to Ceratium (Dinophyceae). Protist. 161(1): 35-54.

GUIRY, M.D. \& GUIRY, G.M. 2015. AlgaeBase. World-wide eletronic publication. National University of Ireland, Galway. Available at: http:// www.algaebase.org. (last access in 16/01/2015)

HALLEGRAEFF, G. \& JEFFREY, S. 1984. Tropical phytoplankton species and pigments of continental shelf waters of north and north-west Australia. Mar. Ecol. Prog. Ser. 20: 59-74.
HALLEGRAEFF, G.M., 1987. Red tides in the Australasian Region. CISRO Division of Fisheries Research, Melbourne.

HARAGUCHI, L.\& ODEBRECHT, C. 2007. Dinophysiales (Dinophyceae) no extremo Sul do Brasil (inverno de 2005, verão de 2007). Biota Neotrop. 10(3): 101-114. http://www.biotaneotropica.org.br/v10n3/en/ fullpaper?bn01910032010+pt (last access in 20/12/2015).

HERNÁNDEZ-BECERRIL, D.U. 1991. The morphology and taxonomy of species of diatom genus Asteromphalus Ehr. J Cramer. Berlin.

IBGE. http://mapas.ibge.gov.br/en/interativos/arquivos/downloads (last access in 30/09/2015)

ISLABÃO, C.A. \& ODEBRECHT, C. 2011. Dinoflagelados (Peridiniales, Prorocentrales) do microplâncton na plataforma continental e talude do extremo sul do Brasil (inverno 2005, verão 2007). Biota Neotrop. 11(3): 153-166. http://www.biotaneotropica.org.br/v11n3/en/ fullpaper?bn02511032011+pt (last access on 20/12/2015)

JANSON, S., BERGMAN, B., CARPENTER, E.J., GIOVANNONI, S.J. \& VERGIN, K. 1999. Genetic analysis of natural populations of the marine diazotrophic cyanobacterium Trichodesmium. FEMS Microbiol. Eco. 30(1): 57-65.

JARDIM, P.F.G. \& CARDOSO, L.S. 2013. New distribution records of Dinophyta in Brazilian waters. Check List. 9(3): 631-639.

KIMOR, B., REID, F.M.H. \& JORDAN, J.B. 1978. An unusual occurrence of Hemiaulus membranaceus Cleve (Bacillariophyceae) with Richelia intracellularis Schmidt (Cyanophyceae) off the coast of Southern California in October 1976. Phycologia. 17(2): 162-166.

KOENING, M.L. \& LIRA, C.G. 2005. O gênero Ceratium Schrank (Dinophyta) na plataforma continental e águas oceânicas do Estado de Pernambuco, Brasil. Acta Bot. Bra. 19(2): 391-397.

KOFOID, A. 1905. New Species of Dinoflagellates. Bull Mus Comp Zool at Harvard College. 50:163-207.

KREFT, H. \& JETZ, W. 2010. A framework for delineating biogeographical regions based on species distributions. J. Biogeogr. 37(1): 2029-2053.

MENEZES, M., MOURA, C. W. N. \& BICUDO, C. E. M. 2015. Algas. Lista de Espécies da Flora do Brasil. (last access in 01/05/2015). Available at: $<$ http://reflora.jbrj.gov.br/jabot/floradobrasil/FB128463>

MONTEIRO, J., LEÇA, E., KOENING, M.L. \& MACEDO, S.J. 2010. New record of Trichodesmium thiebautii Gomont ex Gomont (OscillatorialesCyanophyta) for the continental shelf of northeastern Brazil. Acta Bot Bras. 24(4): 1004-1006.

MOTOKI, A., MOTOKI, K.F. \& MELO, D.P. 2012. Caracterização da morfológia submarina da cadeia Vitória-Trindade e áreas adjascentes-ES, com base na batimetria preditada do topo versão 14.1. Rev. Bras. Geomorfol. 13(2): 151-170.

OKOLODKOV, Y.B. 2014. Dinophysiales (Dinophyceae) of the national park sistema arrecifal veracruzano, gulf of Mexico, with a key for identification. Acta Bot Mex. 106(1): 9-71.

OKOLODKOV, Y.B. \& DODGE, J.D. 1996. Biodiversity and biogeography of planktonic dinoflagellates in the Arctic Ocean. J. Exp. Mar. Biol. Ecol. 202(1): 19-27.

PADMAKUMAR, K.B., MENON, N.R. \& SANJEEVAN, V.N. 2010. Occurrence of endosymbiont Richelia intracellularis (Cyanophyta) within the diatom Rhizosolenia hebetata in Northern Arabian Sea. Int. J. Biodivers Conserv. 2,(4): 70-74.

PEREIRA-FILHO, G.H., ARMANDO-FILHO, G.M., MOURA, R.L. de, BASTOS, A.C., GUIMARÃES, S.M.P.B., SALGADO, L.T., FRANCINIFILHO, R.B., BAHIA, R.G., ABRANTES, D.P., GUTH, A.Z. \& BRASILEIRO, P.S. 2012. Extensive rhodolith beds cover the summits of southwestern atlantic ocean seamounts. J. Coastal Res. 28(1): 261-269.

PINHEIRO, H.T., CAMILATO, V., GASPARINE, J.L.\& JOYEUX, J. 2009. New records of fishes for Trindade-Martin Vaz oceanic insular complex, Brazil. Zootaxa.(2298), pp. 45-54. 
PINHEIRO, H.T., MAZZEI, E., MOURA, R.L., AMADO-FILHO, G.M., CARVALHO-FILHO, A., BRAGA, A.C., COSTA, P.A.S., FERREIRA, B.P., FERREIRA, C.E.L., FLOETER, S.R., FRANCINI-FILHO, R.B., GASPARINI, J.L., MACIEIRA, R.M., MARTINS, A.S., OLAVO, G., PIMENTEL, C.R., ROCHA, L.A., SAZIMA, I., SIMON, T., TEIXEIRA, J.B., XAVIER, L.B. \& JOYEUX, J.-C. 2015. Fish Biodiversity of the VitóriaTrindade Seamount Chain, Southwestern Atlantic: An Updated Database. PLoS ONE. 10(3): 1-17.

PITCHER, T.J., HART, P.J.B., CLARK, M.R.\& SANTOS, R.S. (eds.) 2007. Seamounts: Ecology, Fisheries \& Conservation. $1^{\text {st }}$ ed. Blackwell Publishing, Oxford.

POLAT, S. and KORAY, T. 2002. New records of the genus Histioneis F. R. von Stein (Dinophyceae) from Turkish coastal waters. Turk J. Bot. 26: 481-484.

PROCOPIAK, L.K., FERNANDES, L.F. \& MOREIRA-FILHO, H., 2006. Diatomáceas (Bacillariophyta) marinhas e estuarinas do Paraná, Sul do Brasil: lista de espécies com ênfase em espécies nocivas. Biota Neotrop. 6(3). http://www.scielo.br/pdf/bn/v6n3/v6n3a13.pdf. (last access in 22/12/2015)

PROENÇA, L., TAMANAHA, M. \& FONSECA, R. 2009. Screening the toxicity and toxin content of blooms of the cyanobacterium Trichodesmium erythraeum (Ehrenberg) in northeast Brasil. J. Venom. Anim. Toxins incl. Trop. Dis. 15(2): 204-215.

PROENÇA, L.A.O., FONSECA, R.S. \& PINTO, T.O. 2011. Microalgas em área de cultivo do litoral de Santa Catarina. RiMa Editora. São Carlos.

RAINE, R., WHITE, M. \& DODGE, J.D. 2002. The summer distribution of net plankton dinoflagellates and their relation to water movements in the NE Atlantic Ocean, west of Ireland. J. Plankton Res. 24,(11): 1131-1147.

SATÔ, S., PARANAGUÁ, M.N. and ESKINAZI, E. 1963. On the mechanisms of red tide of Trichodesmium in Recife Northeastern Brazil, with some considerations of the relation to the human disease, "Tamandaré Fever." Trab. do Instit. Oceanogr. da Univ.de Recife. 6(7): 7-49.

SELLNER, K.G. 1997. Physiology, ecology, and toxic properties of marine cyanobacteria blooms. Limnol. and Oceanogr.42(2): 1089-1104.

SILVEIRA, I.C.A. Da, SCHMIDT, A.C.K., CAMPOS, E.J.D., GODOI, S.S. De \& IKEDA, Y., 2000. A corrente do Brasil ao largo da costa leste brasileira. Braz. J.Oceanogr. 48(2): 171-183.

SOUSA, E. de, COSTA, V. da, PEREIRA, L.C.C. \& COSTA, R.M. 2008. Microfitoplâncton de águas costeiras amazônicas: Ilha Canela (Bragança, PA, Brasil). Acta Bot. Bras. 22(3): 626-636.

SUZUKI, R.\& SHIMODAIRA, H. 2006. Pvclust: An R package for assessing the uncertainty in hierarchical clustering. Bioinformatics. 22(12): 1540-1542.
TAYLOR, F.J.R., HOPPENRATH, M. \& SALDARRIAGA, J.F. 2007. Dinoflagellate diversity and distribution. Biodivers. Conserv. 17(2): 407-418.

TENENBAUM, D.R., MENEZES, M., VIANA, S. de C., MENDES, M.C. de Q., EDUARDO, J. \& HATHERLY, M.M.F. 2006. Os Dinoflagelados. In Dinoflagelados e Tintinídeos da região central da Zona Ecoômica Exclusica brasileira: Guia de identificação (D.R. Tenenbaum ed.). Rio de Janeiro: Museu Nacional- Universidade Federal do Rio de Janeiro, p. 35-163.

TENENBAUM, D.R., GOMES, E.T.A. \& GUIMARÃES, G.P. 2007. Microorganismos planctônicos: pico, nano e micro. In Características hidrobiológicas da região central da Zona Econômica Exclusiva BrasileraSalvador, BA ao Cabo de São Tomé, RJ (J.L. Valentin ed.). Brasília: Ideal Gráfica e Editora, p. 83-124.

TIBURCIO, A.S.X. S., KOENING, M.L., MACÊDO, S.J. \& MELO, P.A.M. de C. 2011. A comunidade microfitoplanctônica do Arquipélago de São Pedro e São Paulo (Atlântico Norte-Equatorial): variação diurna e espacial. Biota Neotrop. 11(2): 203-215. http://www.biotaneotropica.org.br/v11n2/ en/fullpaper?bn03811022011+pt. (last access on 20/12/2015).

TUNIN-LEY, A. \& LEMÉE, R. 2013. The genus Neoceratium (planktonic dinoflagellates) as a potential indicator of ocean warming. Microorganisms 1(1): $58-70$

VILLAC, M.C., CABRAL-NORONHA, V.A.D.P. \& PINTO, T.D.O. 2008. The phytoplankton biodiversity of the coast of the state of São Paulo, Brazil. Biota Neotrop. 8(3) http://www.scielo.br/scielo.php?script=sci_ arttext\&pid=S1676-06032008000300015\&lng $=$ en\&nrm=iso\&tlng $=e m$ (Acessed December 2015)

VILLAC, M.C..\& TENENBAUM, D. 2010. The phytoplankton of Guanabara Bay, Brazil: I. historical account of its biodiversity. Biota Neotrop. 10(2). http:// www.scielo.br/scielo.php?pid=S1676-06032010000200030\&script=sci_ arttext. (last access on 20/12/2015).

VILLAREAL, T.A. 1994. Widespread occurrence of the Hemiauluscyanobacterial symbiosis in the Southwest North Altlantic Ocean. B. Mar. Sci. 54(1): 1-7.

WEDEKIN, L., ROSSI-SANTOS, M., BARACHO, C., CYPRIANO-SOUSA, A. and SIMÕES-LOPES, P., 2014. Cetacean records along a coastal-offshore gradient in the Vitória- Trindade Chain, western South Atlantic Ocean. Braz. J Biol. 74(1): 137-144

WOOD, E.1954. Dinoflagellates in the Australian region. Division of Fisheries and Oceanography Technical Paper No. 17, Melbourne.

YOUNG, P.S., 1999. The Cirripedia (Crustacea) collected by the RV Marion Dufresne along the Vitória-Trindade seamounts (Brazil): Brazilian deep water fauna: Results of the oceanographic cruise TAAF MD55. Zoosystema. 21(4): 607-624. 